Grant Armstrong*

\title{
Spanish participios activos are adjectival antipassives
}

DOI 10.1515/tlr-2016-0007

\begin{abstract}
In many languages a set of adjectives are characterized by their "past/ passive" participial morphology. Lexicalist and syntactic approaches to word formation converge on the claim that such adjectives can be derived from verbal inputs with no external argument but never from verbal inputs with an external argument. That is, there are "adjectival passives" but no "adjectival antipassives" marked with the same morphology. I argue that a sub-class of adjectives marked with the "past/passive" participial morpheme -do in Spanish, labeled participios activos in descriptive grammars, should be treated as adjectival antipassives in precisely this sense. I propose that Spanish has an Asp head that (i) is spelled out with "past/passive" participial morphology and (ii) selects an unergative verbal input creating a state/property whose argument corresponds to the external argument of that verbal source. If on the right track, the proposal supports the existence of a typology of adjectivizing heads that are spelled out uniformly with "past/passive" participial morphology but must be distinguished in terms of selectional and semantic properties (Bruening 2014, Word formation is syntactic: Adjectival passives in English. Natural Language and Linguistic Theory 32. 363-422; Embick 2004, On the structure of resultative participles in English. Linguistic Inquiry 35. 355-392). It differs from previous approaches in claiming that such a typology must include root-derived adjectives, as well as 'active (= unergative)' and 'passive' deverbal adjectives.
\end{abstract}

Keywords: adjectival participles, argument structure, distributed morphology

\section{Introduction}

Adjectival participles have received a lot of detailed attention in the literature. Since the seminal study by Wasow (1977), in which the division between verbal and adjectival passives was first proposed, there have been two major threads of investigation regarding adjectival participles. One area addresses the issue of whether these are created by a lexical operation applied to a verbal source

*Corresponding author: Grant Armstrong, University of Wisconsin-Madison, Madison, WI, USA, E-mail: gwarmstrong@wisc.edu 
(see Borer 1984; Bresnan 1995; Dubinsky and Simango 1996; Koontz-Garboden 2010; Levin and Rappaport 1986; Meltzer-Asscher 2011; Wasow 1977 for different implementations of this general approach) or whether they are built syntactically (Alexiadou and Anagostopoulou 2008; Bruening 2014; Embick 2004; Sleeman 2011, among others for different implementations of this general approach). The other area addresses the question of how many types of adjectival participles exist and how to account for their morpho-syntactic and semantic properties (Bruening 2014; Embick 2004; McIntyre 2013; Koontz-Garboden 2010; Kratzer 2000; Meltzer-Asscher 2011; Sleeman 2011, among others).

In this paper I contribute to the latter area by compiling and expanding on a number of observations from the descriptive literature on Spanish participles (mainly Borgonovo 1999; Di Tullio 2008; Felíu 2008; Piera and Varela 1999; Rainer 1999; Real Academia Española 2009; Varela 2002, 2003, 2008) regarding a class of adjectival participles that are labeled participios activos. These adjectival participles are unique in that, in spite of being marked with the "past/passive" participial morpheme -do (=-en/-ed), they appear to be derived from active transitive and unergative verbal sources rather than from passive transitives and unaccusatives. An example that Spanish shares with English is shown in (1).

(1) La profesora es muy leída en la historia romana The professor is very read in the history Roman

'The professor is well-read in Roman history' (i.e. - "the professor has read")

At first blush, adjectival participles like muy leída/well-read seem like idiosyncratic exceptions to more general rules of adjectival participle formation that apply to canonical examples such as closed, frozen and destroyed and this is how they have been treated in most of the literature (an exception is Bresnan 1995). While in English cases like (1) are either rare or may be subsumed under a theory of adjectival participle formation that treats all of them as derivatives of passive/unaccusative verbs (see Bruening 2014; Embick 2004; McIntyre 2013 for observations), it will be demonstrated that such examples in Spanish show much greater degrees of productivity and that many of the idiosyncratic properties of participios activos that are used to relegate them to the status of lexical exceptions are actually properties that apply more generally to all adjectival participles in the language. In light of these observations, their status as a short list of exceptions becomes difficult to defend. The conclusion that I draw from these Spanish data is that there is a class of adjectival participles that are derived from active verbal inputs even though they are marked with "past/ passive" participial morphology in the language. 
This conclusion is defended primarily in Section 2, where a detailed description of participios activos is undertaken. In that section I make four important points regarding participios activos. First, it is demonstrated that they are adjectival (as opposed to verbal) participles that have 'agent/holder' arguments. This property is unexpected if all adjectival participles are derived from passive or unaccusative verbal sources. Second, unlike canonical adjectival participles derived from passive and unaccusative verbal sources, participios activos have implicit 'theme' arguments. For this reason I relabel them as 'adjectival antipassives' (AAs). Third, they can be divided into three classes based on the nature of the operator that binds the event and 'theme' argument variables of the verbal source in the conversion process from verb to adjective. Resultative AAs are like canonical adjectival passives in that the event and implicit argument variables are bound by an existential operator, but there are also two other types of AAs, habitual perfectives and tend-to properties, where the event and 'theme' arguments are bound by a habitual or generic operator, respectively. For example, in (1), the event and theme arguments of the source verb leer (= read) are bound by a habitual operator, which yields an adjective that describes a person who has read many times/things in a particular area of study. Fourth, I show that AAs, like other types of adjectival participles, permit certain types of eventoriented modification and have certain gaps in productivity and special interpretations. After providing the details that properly situate AAs within the bigger picture of adjectival participles, I show in Section 3 that previous analysis of AAs in both English and Spanish can capture some of the data discussed in Section 2 but not all of it, which motivates the need for a new account. I then present a new analysis using the syntactic framework of Bruening (2014) and Embick (2004) in Section 4, showing how this proposal adequately accounts for all of the properties of AAs mentioned in Section 2. Section 5 provides a brief conclusion.

\section{Participios activos $=$ adjectival antipassives: descriptive properties of participios activos}

The objective of this section is to describe the basic properties of participios activos and compare and contrast them with other adjectival participles that are marked with "past/passive" morphology. It is shown that participios activos are unlike more canonical adjectival participles in that they have an argument that corresponds to the external argument of a verbal source and the verbal source has an implicit theme, rather than an implicit agent, argument. This 
characteristic is used as the basis for renaming these as 'adjectival antipassives' (AAs). Apart from this characteristic, they share a number of other properties with more canonical adjectival participles as will be shown in Sections 2.2-2.4.

\subsection{Argument structure: internal vs. external arguments of source verbs}

All adjectival participles have a single argument that is either a head noun in an attributive construction (2a) or an argument in a predicative construction as in (2b).

(2) a. una puerta cerrada

a door closed

'a closed door'

b. La puerta está cerrada

The door is closed

'THE door is closed'

An uncontroversial fact about adjectival participles such as (2) is that they are derived from either passive or unaccusative verbal sources and that the argument of the derived adjective (=puerta in (2)) is interpreted as the internal argument of the passive or unaccusative verbal source (see Borer 1984; Bruening 2014; Levin and Rappaport 1986; McIntyre 2013; Meltzer-Asscher 2011; among others for detailed discussion of this generalization and the different ways that have been proposed to capture it). The main difference that sets participios activos apart from these canonical adjectival participles is that the argument of the adjective in contexts such as (2a) and (2b) does not correspond to the internal argument of a verbal source but rather the external argument. In (3), niño (= child) is the agent of the source verb comer (=eat) rather than the theme.

(3) a. un niño bien comido

a child well eaten

'a very full child' ( = a child who has eaten a lot)

b. El niño está bien comido

The child is well eaten

'The child is very full' (= the child has eaten a lot)

If all adjectival participles were derived solely from passive and unaccusative verbal sources, examples like (3) would be unexpected. One potential way to 
deal with participios activos without having to weaken the passive/unaccusative generalization is to treat cases like (3) as verbs. That is, a possible analysis of (3a) would be a reduced relative clause of an active perfective sentence like that of (4).

(4) un niño (que ha) comido bien

a child that has eaten well

There are number of problems with this idea. First, reduced relative clauses are only possible if the copular verb, ser or estar, is elided but not if the perfective auxiliary haber ( = have) is elided. Second, verbal participles in active sentences are non-agreeing while adjectival participles agree in number and gender with their argument. Since agreement obtains in participios activos as in (5), this supports treating them as adjectives and not verbs.

a. unos niños bien $\left\{{ }^{*}\right.$ comido/comidos $\}$ some children well eaten.sG/eaten.PL

b. una persona bien $\left\{{ }^{*}\right.$ comido/comida $\}$ a person well eaten.mAsc/eaten.FEM

Third, a reduced relative clause would not be able to appear as the complement of a copular verb as in (3b). These observations provide arguments against treating participios activos as reduced forms of active verbs.

Additional arguments that participios activos are indeed adjectives and not reduced active perfective verbs comes from the distribution of the quantifiers mucho ( = a lot) and muy (= very). Observe, for instance, the difference between the active perfective verb ha viajado (= has traveled) and the participio activo, viajada (=well-traveled) in (6). The former only admits the verbal/nominal quantifier mucho ( = a lot) whereas the latter only admits the adjectival quantifier muy ( = very).

a. una persona que $\left\{{ }^{*}\right.$ ha muy viajado / ha viajado mucho\} a persona that has very traveled/ has traveled a lot

b. una persona \{muy viajada/*viajada mucho\} a persona very traveled/ traveled a lot 'a well-traveled person'

In sum, even though participios activos have exceptional argument structure properties, they have the distributional characteristics of canonical adjectival participles and cannot be treated as reduced forms of active perfective verbs. 


\subsection{Implicit arguments of the verbal source}

Much work on adjectival participles has come to the conclusion that part of the process of deriving an adjectival participle from a verbal source involves existentially binding the covert event variable of the source verb and creating a resultant state, and, in some cases, existentially binding the implicit argument variable that corresponds to the agent argument of a passive (see Bruening 2014; Koontz-Garboden 2010; Kratzer 2000; McIntyre 2013; Meltzer-Asscher 2011 for different ways of implementing this). The examples in (7) are derived from passive transitive verbs and describe resultant states of the painting and tying events, respectively. In addition, the implicit agent argument of the passive source is argued to be existentially bound and this is what licenses the presence of by-phrases such as in (7a) as well instrumental PPs that must be under agentive control as in (7b) (see Bosque 1999; Bruening 2014; Gehrke and Marco 2014; Meltzer-Asscher 2011; McIntyre 2013 for different accounts of such modifiers).

(7) a. Este cuadro parece pintado por un niño; no sé por qué This picture seems painted by a child; NEG I know why todos creen que es tan bueno all think that is so good

'This picture seems painted by a child; I don't know why everyone thinks it's so good'

b. Las maletas están amarradas al carro con soga The suitcases are tied to.the car with rope 'The suitcases are tied to the car with rope'

The examples in (8), on the other hand, are derived from the unaccusative sources sentar-se (= sit down) and congelar-se (=freeze), respectively, and thus do not admit, in these contexts, agent-oriented modifiers. These examples involve existential binding of an event variable only and not an implicit agent argument variable.
a. Los alumnos están sentados
The studentes are seated
b. El lago está completamente congelado

The lake is completely frozen

Participios activos also have implicit arguments of a verbal source, but there are important differences in how these argument variables are bound in the 
conversion of verb to adjective. I will show in the next sub-sections that participios activos differ in two ways from canonical adjectival participles. First, instead of having implicit agent arguments that are bound by an operator in the conversion from verb to adjective, they have implicit theme arguments (see Borgonovo 1999; Di Tullio 2008; Felíu 2008; Piera and Varela 1999; Varela 2002, 2003, 2008). This characteristic motivates treating participios activos as adjectival antipassives (AAs), rather than adjectival passives. Second, this theme argument variable as well as the event variable of the verb are unselectively bound not just by existential operators, but also by habitual and generic operators in some cases. The type of operator that binds the theme and event argument variables of the verbal source divides AAs into three different aspectual classes that receive the descriptive labels resultatives, habitual perfectives and tend-to properties. Each of these will be treated in turn.

\subsubsection{Resultatives}

Resultative AAs are quite similar to canonical adjectival participles in that they are resultant states of events that are described by the source verb. Much like canonical adjectival participles can be paraphrased as 'argument is in a state of having been $\mathrm{V}$-ed by $\mathrm{x}$, where $\mathrm{x}=$ an implicit agent', so can resulative AAs be paraphrased as 'argument is in a state of having $\mathrm{V}$-ed some $\mathrm{x}$, where $\mathrm{x}=$ amount of implicit theme.' The examples in (9) illustrate this.

\section{a. Estamos bien comidos}

We are well eaten

'We are really full' ( = we are in a state of having eaten a lot)

b. Juan está bebido

Juan is drunk

'Juan is drunk' (= Juan is in a state of having drunk alcohol)

In (9a), comido (lit. eaten, = full,) describes a state of its argument that is the result of eating some amount of food while bebido (drunk) describes the state of its argument that is the result of drinking some amount of alcohol. Armstrong (2011) has noted that resultative AAs are only possible for verbs that may take unspecified objects in episodic contexts. ${ }^{1}$ For instance, comer (= eat) and beber

1 This generalization is only one side of the coin though. It does not account for why there are not more resultative AAs than are actually attested. This is addressed in Section 2.4. 
( = drink) may appear without an object in an out-of-the-blue, past-tense context. The missing object in each case receives an idiosyncratic interpretation that depends on the verb. In the case of comer, it is 'food' and in the case of beber it is 'liquid', most typically 'alcohol.'
a. ¿Qué pasó? Comimos
What happened? We ate
b. ¿Qué pasó? Juan bebió
What happened? Juan drank

Other transitive verbs may appear without an object in generic contexts (11a) but not in episodic ones as shown in (11b).

(11) a. Los agentes venden

The agents sell

'Agents sell'

b. ¿Qué pasó? Los agentes vendieron *(una casa)

What happened? The agents sold (a house)

According to the generalization described above, comer and beber have AAs because they may appear in the contexts in (10). Since episodic contexts like (10) and resultative AAs both involve existential quantification of an event and implicit theme variable of the verb (by a tense operator in (10) and by the head in which participial morphology is spelled out in (9)), such a connection makes sense. Moreover, note that the idiosyncratic interpretation of the intransitive (unergative) uses of beber ( = drink) in episodic contexts where there is no contextually salient object are maintained in their uses as resultative AAs. The interpretation of $(10 \mathrm{~b})$ that Juan drank alcohol is the same interpretation that can be observed in (9b), which follows straightforwardly if resultative AAs are actually derived from unspecified object constructions and receive episodic interpretations based on the operator that binds the relevant variables in the source verb.

Empirical support for this generalization can be found in the fact that outside of comido and bebido there are only a handful of other resultative AAs and all may appear with unspecified objects in episodic contexts. As noted by Di Tullio (2008) and Felíu (2008), many speakers accept resultative AAs of other consumption verbs such as almorzado (lit. lunched,= having eaten lunch,), cenado (lit. dined, = having eaten dinner,) and desayunado (lit. breakfasted, = having eaten breakfast,). All of these verbs appear as intransitives with unspecific objects in episodic contexts as shown in (12). 


$\begin{array}{cll}\text { ¿Qué pasó? } & \text { Almorzamos / cenamos / desayunamos } \\ \text { What happened? } & \text { We ate (lunch) } & \text { / We ate (dinner) }\end{array}$

In these cases, the existential implicit object is a meal eaten at a particular part of the day. In addition to these, there are three other resultative AAs that I have been able to isolate. These are shown in (13).

(13) a. Marcos está fumado

Marcos is smoked

'Marcos is stoned/high'

b. Le estoy agradecida

DAT.3s I am thanked

'I am thankful/grateful to her (for some specific help she provided)

c. Están muy sudados

They are very sweated

'They are very sweaty'

All of these verbs can appear in an episodic context without a theme argument as in (12), but these differ somewhat from the consumption verbs described above.
¿Qué pasó?
Marcos fumó
/ Le agradecí /
Sudaron
What happened? Marcos smoked / I thanked her / They sweated

The interpretation of fumado in (13a) is that 'Marcos is in a state of having smoked some mind-altering substance', which can be metaphorically extended to describe being 'crazy' or 'out of it.' When fumar is used intransitively as in (14), its object is most naturally interpreted as 'tobacco.' Thus, there does not seem to be as close an alignment between bebido and intransitive beber and fumado and intransitive fumar. A potential way of accounting for this is that salient resultant states are more easily to identify if some behavior-altering substance has been consumed. In (13b) the missing object refers to 'some help/some helpful deed.' While this argument cannot be expressed in the resultative AA, it can appear as the direct internal argument of the verb agradecer as in (15).
(15) Le agradecí la ayuda
DAT.3s I thanked the help
'I thanked her for her help'

Finally, the unergative verb sudar (sweat) gives rise to a resultative AA. Following Hale \& Keyser's (2002) proposal regarding the internal structure of 
unergatives, I propose that the existential implicit object in this case is 'some amount of sweat.' The argument of sudado is interpreted as 'having produced some amount of sweat.'

In this subsection, we have seen that resultative AAs involve existential quantification of an event variable and an implicit theme of the verbal source. It was demonstrated that only verbs capable of licensing an unspecified object in an episodic context can give rise to resultative AAs. This generalization has a simple explanation if resultative AAs are derived from unspecified object constructions.

\subsubsection{Habitual perfectives}

Unlike resultative AAs, habitual perfective AAs represent a quite different way of creating an adjectival participle than has been previously described for canonical adjectival participles. Take the examples in (16) as a starting point.

a. La profesora es muy leída

The profesor is very read

'The professor is well-read'

b. El correspondiente es muy viajado

The correspondent is very traveled

'The correspondent is well-traveled'

In (16a), leída describes a property of its argument that has been attained through reading many works in a particular scientific or literary field while viajado in (16b) describes a property of its argument that has been attained through traveling to many places and learning a lot about them. It is clear based on these descriptions that we cannot appeal to existential quantification of event and implicit theme variables in order to correctly account for habitual perfective AAs. If anything, there is an intuitive correlation between the active perfective examples in (17) and the AAs in (16).

(17) a. La profesora ha leído mucho

The professor has read a lot

b. El correspondiente ha viajado mucho

The correspondent has traveled a lot

Habitual perfective AAs derived from dynamic verbs are restricted, as far as I can tell, to the semantic fields of being 'learned' or 'worldliness/having a lot of 
certain types of life experiences.' Those AAs that are built from verbs of learning are leído (read), estudiado (lit. studied, = learned/wise) ${ }^{2}$ and entendido (lit. understood, = learned), while those based on worldliness are viajado (traveled), vivido (lit. lived, = worldly,), sufrido (lit. suffered,=long-suffering) and experimentado (experienced). Some examples are shown in (18).
a. \%Juana es muy estudiada
Juana is very studied
'Juana is well-read/learned'
b. Juan es muy vivido
Juan is very lived
'Juan is very worldly'

The simplest way to account for habitual perfective AAs is to posit that the participial morphology that converts the source verb to an adjective binds the event variable and implicit theme argument with a habitual operator rather than an existential one. Thus, someone who is muy leido (= well-read) is not someone who is 'in a state of having read something' ( = resultative AA) but someone who has read many times/many different things in a particular area of study. ${ }^{3}$

\subsubsection{Tend-to properties}

A final type of AA is derived from an event and implicit theme that are interpreted generically. These lack a resultative or habitual perfective readings and instead describe something that the argument tends to do. For example, in (19) below, there is no sense in which the AA describes the result of some trusting, boasting or boring event or that the arguments have attained these properties through habitually trusting, boasting or boring; these are simply properties that characterize their argument because they tend to trust, boast and bore. I will call such AAs 'tend-to properties.'
a. Juana es confiada
Juana is trusted
'Juana is naive/innocent (overly trusting of others)'

2 This particular AA is not accepted by all speakers, which has been indicated with the $\%$ symbol in example (18a).

3 The reader will have noted that these examples all contain muy (= very), without which the sentences range from slightly unnatural to unacceptable for some speakers. This will be addressed in Sections 2.3 and 4.2 below. 

b. Pedro es presumido
Pedro is boasted
'Pedro is conceited'
c. El profesor es aburrido
The professor is bored
'The professor is boring'

Tend-to property AAs are related to generic unergative expressions like those in (20) that have been called 'characterizing expressions' in the literature (Krifka et al. 1995; RAE 2009)
(20) a. Juana confía
Juana trusts
b. Juan presume
Juan boasts
c. El profesor aburre
The professor bores

Varela (2002) has argued that participios activos built from object experiencer verbs like aburrir (bore) have an arbitrary pro $\left(=\right.$ pro $_{\mathrm{ARB}}$ ) object that is interpreted as 'people in general.' This claim makes sense of many aspects of tend-to property AAs. First, following Rizzi’s (1986) claim regarding the temporal environments in which pro ${ }_{\mathrm{ARB}}$ may appear, it accounts for why there must be an underlying present-tense verbal structure that is compatible with a generic reading. Second, it accounts for why object experiencer verbs are quite productive in giving rise to tend-to property PAs. As Rizzi (1986) notes, only certain classes of verbs may select pro $_{\mathrm{ARB}}$ as their object. Since object experiencer verbs may take pro $_{\mathrm{ARB}}$ as a verbal argument and pro ${ }_{\mathrm{ARB}}$ is a necessary component for deriving tend-to property AAs, we can explain why this particular class of verbs semi-productively gives rise to them. However, it does not account for the many types of verbs that have tend-to property AAs outside of this class. For example, the implicit object in (20b) (= presume) is not interpreted as 'human', which is a defining characteristic of pro $_{\mathrm{ARB}}$. This can be remedied by claiming that there exist both human and non-human missing objects, both with generic meanings. Mittwoch (2005) labels these 'missing persons' and 'missing things.' In the case of (20b) we have a missing thing, giving rise to the interpretation that Juan boasts about 'things in general.' If there are two types of implicit objects, one referring to humans and one referring to things, then tend-to property AAs may be separated into two classes based on whether the generic missing object is human or not. This is shown in (21). 
(21) Missing human objects (interpreted generically) ${ }^{4}$

a. aburrido (lit. bored,= boring); animado (lit. livened, =lively); cansado (lit. tired, = tiring); confuso (lit. confused, = confusing); descansado (lit. relaxed, = relaxing); distraído (lit. distracted, = entertaining); divertido (lit. amused, = amusing); entretenido (lit. entertained, = entertaining); fastidiado (lit. irritated, = irritating)

b. confiado (lit. trusted, =trusting); considerado (lit. considered, = considerate); desconfiado (lit. mistrusted, = mistrusting); descreído (lit. unbelieved, = unbelieving)

The rest of the tend-to property AAs have missing things. A non-exhaustive list of these is shown in (22).

(22) Missing thing objects (interpreted generically) agarrado (lit. grasped, =stingy); apañado (lit. fixed up, =handy); aprovechado (lit. taken advantage of, = resourceful); desperdiciado (lit. wasted, = wasteful); desprendido (lit. detached, = generous); disimulado (lit. concealed, = reserved); disipado (lit. squandered, = wasteful); fingido (lit. pretended, =tricky); bienhablado (well-spoken); mirado (lit. looked, = circumspect); moderado (lit. moderated, = moderate); negado (lit. denied, = useless); pensado (lit. thought, = thoughtful); ponderado (lit. analyzed, = prudent); porfiado (lit. strived, = stubborn); precavido (lit. watched after, = cautious); presumido (lit. boasted, = conceited); etc.

In keeping with the previous sub-sections, the simplest way to connect these AAs with resultatives and habitual perfectives is to claim that the participial morphology in these cases binds the event and theme argument variables of the verb with a generic operator rather than an existential or habitual one.

To conclude this entire section, what has been shown in the previous subsections is that, in spite of their exceptional argument structure properties, participios activos are created by a conversion process in which an event and implicit argument variable are bound by an operator, which is quite similar to

4 For the object-experiencer verbs in (21a) one might wonder whether the theme/stimulus argument is really 'external' in the relevant sense. These correspond to the preoccupare-type in Belletti and Rizzi (1988) in which the theme/stimulus is analyzed as originating in a VP-internal position. I will follow Arad (2002) in assuming that the theme/stimulus arguments are merged in root-external positions and may have active or stative causative interpretations depending on the flavor of Voice/ $v$ that merges. The main point here is that, like other external arguments, the theme/stimulus arguments of these verbs are merged in a projection external to the root and thus qualify as AAs given the definition in Section 2.1. 
what happens with canonical adjectival participles. The main differences between participios activos and canonical adjectival participles are that the former are adjectival antipassives that involve 'exportation' of the external verbal argument and binding of an implicit internal verbal argument and the operator that binds the event and implicit argument variable of the source verb is not always existential but may be existential, habitual or generic.

\subsection{Modification}

An additional area in which canonical adjectival participles can be compared with AAs concerns modification. Many diagnostics of the internal structure of adjectival participles are based on the types of agent and event-oriented modifiers that are licensed by adjectival participles in addition to how the dimension of degree quantifiers is determined. Let us consider how such modification facts apply to AAs.

As discussed at the beginning of the previous section, part of the motivation of deriving canonical adjectival participles from passive source verbs is that they can be modified by agent-oriented modifiers such as by-phrases ( $c f$. example 7 above). PP modifiers that identify the implicit theme argument of AAs are also possible as in (23).

(23) a. La profesora es muy leída en la historia romana

The professor is very read in the history Roman

'The professor is well-read in Roman History'

b. El es muy confiado en las personas

$\mathrm{He}$ is very trusted in the people

'He is overly trusting of other people'

However, as is the case with by-phrases in adjectival participles derived from passives (see references at the beginning of Section 2.2), these PP modifiers are not productive as shown in (24).

(24) a. ${ }^{\star}$ Estamos comidos de pescado

We are eaten of fish

Intended: We are full of fish (= we are in a state of having eaten fish)

b. *Están bebidos de vino

Theyare drunk of wine

Intended: They are drunk on wine

The type of modification in (23) marks a similarity between AAs and canonical adjectival participles, but they differ with respect to event-oriented modifiers. 
Many adjectival participles derived from passive and unaccusative verbs admit adverbial modifiers that target some aspect of the event that is described by the source verb as in (25) (see Bruening 2014; Koontz-Garboden 2010 and MeltzerAsscher 2011 for more examples from English).

a. El cuarto quedó cuidadosamente limpiado

The room remained carefully cleaned

'The room remained carefully cleaned'

b. un tren recién llegado

a train recently arrive

'a recently arrived train'

All types of AAs, on the other hand, seem to systematically reject event-oriented modifiers as shown in (26).

(26) a. Juan está (*deliberadamente / *recién) fumado

Juan is deliberately / recently smoked

Intended: 'Juan is deliberately/recently high ( = he is in a state of having deliberately / recently smoked something to make him high)

b. María es muy leída ( ${ }^{*}$ con esfuerzo)

María is very read with effort

Intended: 'María is well-read with effort ( = she has attained a state of being well-read by reading with a lot of effort)

c. Ese profesor es ( ${ }^{*}$ rápidamente) aburrido

That professor is rapidly boring

Intended: That professor bores people rapidly

However, some AAs are compounds that contain a bound adverbial modifier with an event-oriented interpretation as in (27).

(27) un abogado bien-hablado

a lawyer well-spoken

'a well-spoken lawyer'

In (27) bien is a bound manner modifier that is required to form this particular tend-to property AA, which means that the lawyer 'tends to speak well.' Compounds such as (27) are rare in Spanish but more common in English canonical adjectival participles and AAs (cf. Bowers 2010; McIntyre 2013).

(28) a. a student-led protest (Agent)

b. an oft-cited case (Adverbial) 
Finally, what AAs do readily admit are degree quantifiers that have eventoriented interpretations. This characteristic of some degree terms has been noted by Bosque (1999) and Kennedy and McNally (2005) for canonical adjectival participles like (29).

(29) a. a much admired statesman (K\&M 2005: 364)

b. un museo muy visitado (Bosque 1999: 297)

a museum very visited

In (29a) much does not appear to be interpreted as fixing a degree of 'admiredness' but rather seems to be sensitive to the verbal argument and event structure that they inherit. For instance, it could mean that 'a lot of people admire the statesman' or that 'he has been admired for a long time.' Likewise, in (29b) muy is not intensifying a property of 'visited-ness' but rather indicates that the museum is visited often or by many people. Kennedy and McNally (2005) explain this variety of readings in the following terms:

Any of the various aspects of verb meaning that support measurement (temporal extent, number of occurrences, number of participants, intensity, etc.) can be used to fix the dimensional parameter of the derived adjective's scale. We may assume that any particular adjectival form (needed, admired, etc.) is compatible with several dimensions, one of which must be settled upon in a context of utterance. (Kennedy and McNally 2005: 364)

In AAs, degree morphology is sensitive to a variety of dimensions, some of which are clearly related to the verbal structure from which they are derived and others that are more appropriately understood in terms of the derived state or property that is formed. Consider the examples in (30).
(30) a. Estân
bastante bebidos
They are quite drunk
'They are quite drunk'
b. María es muy viajada
María is very traveled
'María is well-traveled'
c. Un comediante bien entretenido
A comedian well entertained
'A really entertaining comedian'

The dimension of the scale in (30a) may be the amount of alcohol, which is derived from the verbal structure, or the state of drunkenness that results from the drinking event. In (30b), the dimension of the scale can only be understood 
in terms of verbal structure from which the adjective is derived. It may refer to the number of places to which Maria has traveled or the amount of times that María has traveled to a particular area, or both. However, there is no sense in which the degree modifier may be understood as fixing a degree on a scale of the property of "traveled-ness." Finally, the dimension of the scale in (30c) is one of intensity. It does not appear to refer to the number of times the comedian entertains nor the amount of people that he tends to entertain.

In this section, it has been shown that, like canonical adjectival participles, AAs also admit different types of modification that provide indirect evidence of their derivational history. Like canonical adjectival participles, they admit PPmodifiers that identify the implicit verbal arguments and give rise to eventoriented interpretations of degree quantifiers. On the other hand, AAs are more limited in their ability to take adverbial event-oriented modifiers than canonical adjectival participles.

\subsection{Productivity and semantic drift}

Some important facts that will not have escaped the reader are that AAs are semi-productive within certain semantic fields such as verbs of consumption, learning, traveling and object-experiencer psychological verbs and also exhibit a strong tendency toward "semantic drift" with respect to their source verbs. The exceptional argument structure properties of AAs, coupled with their lack of productivity and tendencies to yield unpredictable meanings, could be used as grounds to treat them as atomic/stored lexical entries, as opposed to canonical adjectival participles, which are more productive and show more regularity in terms of meaning. On the other hand, gaps in productivity of canonical adjectival participles have been noted for both passive and unaccusative source verbs (Bruening 2014; Kratzer 2000; Meltzer-Asscher 2011; McIntyre 2013; among

5 I use the term 'semantic drift' following Bruening (2014), Horvath and Siloni (2008) and Meltzer-Asscher (2011). It is meant to describe a particular meaning ascribed to an adjectival participle that is not derived from the verbal source. For instance, the following example from Bruening (2014: 405) and Horvath and Siloni (2008: 124) demonstrates that related (in the familial) sense is a meaning that only appears with the adjective and not with a passive verb.

(i) These two are obviously related ( $\neq$ These two have been/are being related to one another)

In the Spanish grammatical tradition, this particular phenomenon is described in terms of lexicalization or recategorization of a participle as an adjective with a meaning independent of the verbal source (see Bosque 1999: 281-283 for a discussion of this). 
others) and 'semantic drift' or 'lexicalization' of canonical adjectival participles has been documented in many languages (Bosque 1999; Bruening 2014; Di Tullio 2008; Horvath and Siloni 2008; Meltzer-Asscher 2011). So, in principle, it should be possible to account for lack of productivity and 'semantic drift' in AAs in the same way that they are accounted for with canonical adjectival participles. I will briefly discuss two issues related to lack of productivity and 'semantic drift' in AAs and show how these are not problems unique to AAs, but to adjectival participles in general. This being so, this does not constitute a reason to treat AAs differently in either a lexicalist or syntactic theory of adjectival participle formation.

Let us start with lack of productivity, using resultative AAs as a case in point. Recall from Section 2.1 that a generalization regarding this class of AAs is that only verbs capable of taking unspecified objects in episodic contexts can have resultative AAs. However, this generalization, as is, over-generates. For example, it does not explain why verbs outside of the consumption class that have missing objects in episodic contexts do not give rise to resultative AAs. For instance, there are no resultative AAs for creation verbs such as pintar (paint) and tejer (sew) and performance object creation verbs such as bailar (dance) and cantar (sing), which is shown in (31).

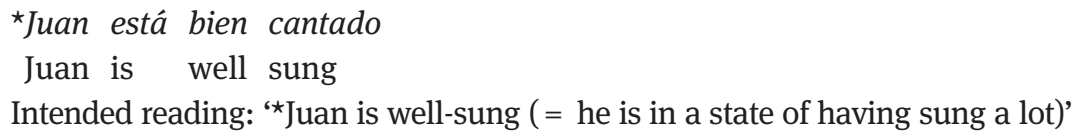

Thus, there must be an additional restriction imposed, perhaps related to idiosyncratic semantic features of groups of lexical items or certain diachronic aspects of lexical items that are not obviously accessible to modern speakers, in order to account for which resultative AAs are actually acceptable and which ones are not. This is reminiscent of constraints on unaccusative inputs to adjectival participle formation described in McIntyre (2013). Not all unaccucative verbs give rise to adjectival participles as shown in (32).
(32) a. *The guests are arrived
b. *The prisoners are fled/escaped
c. ${ }^{\star}$ The audience members are entered/left

This means that internal argumenthood is a necessary but not sufficient condition for giving rise to an adjectival participle and there must an additional condition that filters out the unacceptable forms in (32). In sum, the lack of productivity in AAs is not unique in the realm of adjectival participles. 
Let us now consider the issue of 'semantic drift' that is present in many AAs. For resultative and habitual perfective AAs, there are few, if any, cases of semantic drift that go beyond metaphorical extension of the state or property derived from the verbal source. For instance, fumado (lit. smoked, 'stoned/high') might be extended to domains that include states that do not involve smoking something but apply to behavior reminiscent of someone who has (= 'crazy', 'out of it'). Likewise, viajado ( = traveled) is a property that requires that the traveler actually have some in depth knowledge of the places she has been to. On the other hand, there are many cases of 'semantic drift' in tend-to properties. Two clear examples are agarrado ('stingy', derived from the verb meaning 'to grasp') and negado ('useless', derived from the verb meaning 'to deny). If agarrado were to maintain the meaning of its source verb, we expect the generic characterizing statement in (33) to have a meaning akin to 'not spend money', but this is not the case.

\section{(33) Felipe agarra}

Possible: Felipe grabs people/things

Impossible: Felipe doesn't spend his money

Instead, agarrado has a meaning as an adjectival participle that is not directly derived from the verb agarrar (= grasp). However, as mentioned above, there is nothing about this particular phenomenon that singles out AAs with respect to other adjectival participles. As Bosque (1999: 283) notes, the adjectival participle autorizado (lit. 'authorized' = 'expert') has a special meaning when it combines with the head noun opinion (= opinion) that is not related to the verb autorizar ( = to authorize).

(34) una opinión autorizada

an opinion authorized

'an expert opinion' ( $\neq$ an opinion that has been authorized)

To conclude this section, we have seen that AAs are not fully productive and can exhibit significant semantic drift with respect to the verbal source. However, these characteristics can also be observed in canonical adjectival participles, and thus should ideally receive a similar or identical explanation.

\subsection{Summary}

The main objective of this descriptive section has been to demonstrate that participios activos are adjectival antipassives (AAs) and that they share many 
properties with canonical adjectival participles but differ in two key respects: they have 'external' verbal arguments and the event and argument variables in their source verbs may be bound by one of three flavors of an aspectual operator (existential, habitual or generic). Approximately 100 participios activos have been described in the literature cited in this section. This, in addition to the fact that many speakers interpret and use novel participios activos that are not registered in any dictionary ( $c f$. Felíu 2008) indicate that they constitute more than a small list of exceptions to the general rule regarding adjectival participles and should be integrated into general theories of the phenomenon. Table 1 summarizes the properties of participios activos with respect to canonical adjectival participles.

Table 1: Participios activos and canonical adjectival participles.

\begin{tabular}{|c|c|c|}
\hline Property & Participios activos & $\begin{array}{l}\text { Canonical adjectival } \\
\text { participles }\end{array}$ \\
\hline Verbal sources & $\begin{array}{l}\text { Active transtives; } \\
\text { unergatives }\end{array}$ & $\begin{array}{l}\text { Passive transitives; } \\
\text { unaccusatives }\end{array}$ \\
\hline $\begin{array}{l}\text { Operators that bind event } \\
\text { variable of source verb }\end{array}$ & Existential; habitual; generic & Existential \\
\hline Modification by PP & $\begin{array}{l}\text { Identifies internal argument } \\
\text { of source verb }\end{array}$ & $\begin{array}{l}\text { Identifies external argument } \\
\text { of source verb }\end{array}$ \\
\hline $\begin{array}{l}\text { Event-oriented adverbial } \\
\text { modification }\end{array}$ & $\begin{array}{l}x \\
\text { (extremely limited) }\end{array}$ & $\begin{array}{l}\checkmark \\
\text { (subject to certain semantic } \\
\text { restrictions) }\end{array}$ \\
\hline $\begin{array}{l}\text { Event-oriented interpretation } \\
\text { of degree terms }\end{array}$ & $\checkmark$ & $\checkmark$ \\
\hline Limits on productivity & $\begin{array}{l}\checkmark \\
\text { (limited to certain semantic } \\
\text { fields) }\end{array}$ & $\begin{array}{l}\checkmark \\
\text { (limited to certain lexical } \\
\text { semantic classes) }\end{array}$ \\
\hline Semantic drift & $\checkmark$ & $\checkmark$ \\
\hline
\end{tabular}

\section{Previous analyses}

In this section I discuss previous approaches to AAs and demonstrate that none of them gives a fully adequate account of the properties of AAs that were laid out in Section 2. 


\subsection{Lexicalist analyses}

There are two lexicalist analyses of AAs in the literature. Bresnan (1995) first noted that English has adjectival participles with agent arguments as in (35).

(35) a. well-prepared students ( = students who have prepared well)

b. (un)declared majors ( = students who have (not) declared a major)

c. a confessed killer ( $=$ a killer who has confessed)

She uses these examples, in addition to other limits on adjectival participle formation, to motivate an analysis of adjectival participles in terms of semantics rather than syntactic structure. Specifically, the argument of an adjectival participle is not necessarily the direct internal argument of a verbal source, but rather is contingent on whether the argument has undergone a change that yields a salient result state. While this analysis could be applied to the resultative AAs and habitual perfective AAs described in Sections 2.1 and 2.2, it is unclear how it could be extended to habitual perfective and tend-to property AAs, which do not involve result states. For instance, the interpretation of the tend-to property AA aburrido (lit. bored, = "boring") does not describe the result of having bored other people.

Varela (2002, 2003, 2008) claims that AAs are derived by merging an adjectivizing head with a verbal structure in a lexical component of the grammar. In these works, Varela argues that AAs are one possible result of merging a stativizing head with a verb's lexical conceptual structure (LCS, see Levin and Rappaport Hovav 1995). In Varela (2008), she claims that the stativizing head, which is realized by participial morphology in most cases, is [-eventive] and can combine with at least three different LCS structures as shown in (36).

(36) a. las manos secadas

that hands dried

[state [CAUSE $\left([]_{\text {agent }}\right.$ [BECOME $\left.\left.\left.\left.\left([]_{\text {theme }}\right)\right]\right)\right]\right]$

b. las manos secas

that hands dry

[state [BECOME ([ ] $\left.\left.\left.]_{\text {theme/experiencer }}\right)\right]\right]$

c. un hombre muy entendido

a man very understood

'a very learned man'

[state $\left.\left[\mathrm{DO}_{[- \text {-tel] }}\left([]_{\text {experiencer }},[]\right)\right],[]_{\text {manner }}\right]$ 
The examples in (36a) and (36b) correspond to passive and unaccusative bases of canonical adjectival participles. The structure in (36c) is meant to derive various aspects of AAs. The proposal is that AAs originate as verbs that are decomposed into the predicate Do and two arguments, one corresponding to an experiencer and one a null theme. The predicate Do describes an undelimited manner of acting. Its undelimitedness is the source of the label [-tel] while its manner component is represented as a modifier of the whole structure. AAs work as follows: the derived adjective describes a state that is attained by the experiencer in the LCS of (36c) through doing the action described by the verb many times or with a certain intensity. Since the verb is not inherently delimited, part of the conversion process from verb to adjective is determining some bound on the number of times/intensity with which the action must be performed. According to this analysis, this is the function of the manner predicate in the LCS in (36c). For AAs such as entendido (= learned) that do not require modifiers, the amount of understanding is determined contextually and manner has no modifier. However, in other cases such as bienhablado (= well-spoken), the manner modifier is necessary to establish some boundary on the event in the conversion from verb to adjective.

Varela's (2002, 2003, 2008) approach attempts to account for all AAs as if they were habitual perfectives, which seems plausible for entendido (lit. understood, = learned) but not for bienhablado ( = well-spoken) or for resultatives such as comido (lit. eaten, = full)). Note that bienhablado and its English counterpart well-spoken, do not describe someone who has come to attain the state of speaking well through many acts of speaking well in the past. It simply describes someone who tends to speak well. Treating it otherwise is somewhat confusing and it leads to the questionable move of linking bien (= well), a manner modifier, with some delimitative capacity in the conversion of the verb to an adjective, which it does not appear to have.

While these two lexicalist analyses of AAs can account for some of them, they do not provide adequate coverage of the full range of AAs that were presented in Section 2.2. The main problems stem from not separating distinct classes of AAs from each other.

\subsection{Syntactic analyses}

There are two syntactic analyses of adjectival participles that have addressed the English examples first noted in Bresnan (1995): Embick (2004) and Bruening (2014). Embick (2004) claims that examples like a confessed killer are examples of adjectival participles that are not derived from a verbal source, which are 
called 'stative participles' in the proposed system. In order to understand the status of stative participles, it is necessary to go into some details regarding how participles are formed in this theory. They are created by merging an Asp head with a verbal structure or directly with an acategorial root, which yields three possible types as in (37).
a. The door was closed by John
(eventive passive)
b. The door looked carefully closed
(resultative participle)
c. The door was built closed
(stative participle)

The differences between these three types of participles are accounted for by claiming participial morphology is the spell-out of different aspectual heads that have different selectional properties and meanings. In eventive passives, Asp selects an agentive verb that projects no specifier. The agentive verb contains an AGENT predicate that may be modified with a by-phrase, which accounts for why eventive passives admit by-phrases whereas resultative and stative participles do not. Resultative participles contain a distinct aspectual head, $\mathrm{Asp}_{\mathrm{R}}$, which selects a different type of verb, $v_{[\mathrm{FIENT}]}$. This verb describes an event of change and introduces the argument that undergoes the change in its specifier. Asp $\mathrm{p}_{\mathrm{R}}$ stativizes the event described by $v_{\text {[FIENT] }}$. This is meant to account for the observation that resultative participles do not admit by-phrases but do admit event-oriented modifiers such as carefully (37b). Finally, stative participles contain a third type of aspectual head, Asp. This aspectual head is root-selecting and creates an adjective from a root. Unlike eventive passives and resultative participles, stative participles do not entail an event.

Embick (2004) suggests that cases like (35) are instances of stative participles that involve $\mathrm{Asp}_{\mathrm{S}}$ merging directly with a root. He adopts an idea first proposed by Alec Marantz (see Marantz 2013 and references therein) that the first categorizing head that merges with a root defines a domain of special form and meaning. Since $\mathrm{Asp}_{\mathrm{S}}$ merges directly with a root, idiosyncrasies in form and meaning are to be expected. One such idiosyncrasy in meaning is the fact that the adjectival participles in (35) have agent arguments. While this account could potentially be applied to the examples in English cited by Bresnan (1995) and explain why event-oriented modifiers are not admitted in these cases, many difficulties arise if we attempt to apply it to the Spanish data presented in Section 2. From the formal perspective, all AAs have verbal theme vowels (which are glossed as TV in the lists presented in Section 2) and some derivational verbal morphology. Within the Distributed Morphology (DM) framework employed by Embick (2004), it has been argued that verbal theme vowels and derivational verbal morphology are vocabulary items that spell out the presence 
of a $v$ head (see Embick and Noyer 2007 and especially Oltra-Massuet 1999, 2014 and references therein). If AAs are treated as stative participles, the consistent presence of a verbal theme vowel and/or derivational verbal morphology is unexpected. From the interpretative perspective, it was shown that, even though there are limitations on event-oriented modifiers in AAs, there exist systematic relations between the events described by active transitive and unergative verbal sources and derived AAs that would be left mainly to chance if these were underived adjectives. For these reasons, I rule out treating AAs as stative participles.

Another syntactic approach to AAs based on English data is outlined in Bruening (2014). Unlike Embick (2004), Bruening (2014) argues that all adjectives with participial morphology are derived from a verbal source which may be either a passive transitive or an unaccusative. The main claim in Bruening (2014) is that all examples of apparent active adjectival participles in English are really instances of passives. They appear to be active participles because the internal argument that is externalized during the adjectivization process is either co-referential with an agent (= reflexive) or is the argument of a covert passive causative verb. For instance, in (35a), well-prepared students are "students $_{i}$ who have been prepared __ _ well (by themselves)”, in (35b) (un)declared majors are "students $s_{i}$ who have (not) been made _ _i to declare a major" and in (35c) a confessed killer is "someone ${ }_{i}$ who has confessed to being _ Once the meanings of these derived adjectives are properly understood, it is possible to maintain the strong generalization that all adjectival participles are derived from verbal structures in which an internal argument is 'externalized.' Bruening (2014) presents a plausible argument that nearly all of the English examples that appear to be active adjectival participles could be derived from the types of passive structures mentioned above, but the Spanish data presented in Section 2, when considered in its entirely, is less amenable to this suggested analysis.

Let us first explore the possibility that covert passive causatives are behind what we observe for AAs in Spanish. If on the right track for Spanish, it would mean that resultative AAs like estar comido ( = lit. be eaten, = "be full") would be derived from a structure meaning something like "someone $\mathrm{e}_{\mathrm{i}}$ who is in a state of having been made ___ to eat (something)" (see Di Tullio 2008 for a suggestion along these lines). However, there is no entailment that the argument of comido (=eaten) or bebido (= drunk) in addition to newer forms such as fumado (= smoked), cenado (= dined), almorzado (= lunched) or desayunado (= having eaten breakfast), is an undergoer that has been 'fed' or 'made to consume', even though this is possible in some cases. If these were all derived from covert passive causatives, we would expect a strict entailment pattern in which an 
implicit external argument distinct from "consumer" would always be interpreted or somehow identifiable. I am aware of no such entailment pattern for resultative AAs generally. In addition, it would be very difficult to extend this idea to habitual perfective AAs and tend-to property AAs. Habitual perfective AAs such as muy leído ( = well-read) do not involve the presence of an implicit external causer that "makes someone read many things." Likewise, tend-to property AAs are clearly not derived from covert passive causatives that yield a resultant state. When confiado (= trusting) is used, it is does not entail that the argument of the adjective "has been made to overly confide in people." In conclusion, while the possibility of analyzing some cases of AAs as coming from covert passive causative structures, this is not a promising way of accounting for the general phenomenon described in Section 2.

Alternatively, all instances of AAs may be derived from reflexive interpretations of passive transitives as in the case of well-prepared mentioned above. The main problem with this idea is that, as discussed at length in section 2, the direct internal argument of the source verb is always implicit in AAs and there are systematic connections between unergative verbal constructions in certain tense/aspects and AAs. If AAs were derived from reflexive interpretations of passives, we would expect the internal argument position of the verb to be linked to the external argument position of the adjective, but this is not the case in any of the classes of AAs we have seen: comido (=someone who has eaten, not someone who has been eaten (by himself)), leído (= someone who has read, not someone who has been read (by himself)) and apañado (= someone who fixes things, not someone who has been fixed (by himself)).

\subsection{Summary}

In this section, lexicalist and syntactic analyses of AAs in Spanish and related types of examples in English have been discussed in terms of how they might account for the data presented in Section 2. While each of the accounts is able to explain some of the examples in section, there is no account that can capture the entire range of AAs as discussed in Section 2. As shown here, when considered in its entirety, the data in Section 2 represent a problem for current theories of adjectival participle formation regardless of whether or not modular distinctions are appealed to. Since the main objective of this paper is simply to outline an analysis that can capture these basic properties, I will not take a stance on this issue in the next section and will propose an analysis of AAs by modifying the syntactic framework of Embick (2004) and Bruening (2014). 


\section{Proposal}

The most basic property of AAs that is not readily accounted for in previous analyses is that that an external argument of the source verb is interpreted as the argument of the adjective. In order to capture this, I propose that all AAs are derived from an Asp head (Embick 2004) with the following properties: (i) it is spelled out by past participial morphology (represented by $-d$ en (38b)), (ii) it selects an active verbal complement rather than a passive or unaccusative one and (iii) it creates an adjective from that verbal complement of which the external argument of the verb (in spec Voice) is interpreted as the argument of the adjective. This is shown in (38). ${ }^{6}$

(38) AAs in Spanish are derived from Asp

a. Selectional property of Asp, [S:Voice $(+\mathrm{spec})]$

b. Structure of Asp

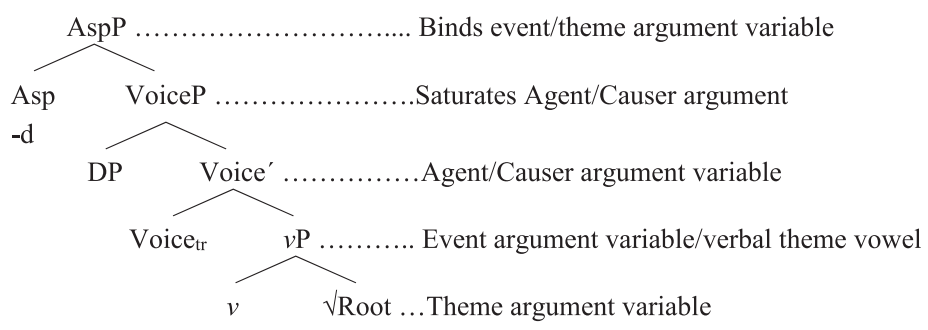

The structure in (38) accounts for why AAs have the argument structure they do without having to propose covert passive causative constructions or reflexive passive inputs that do not yield the correct interpretations as discussed in Section 3.2 above. However, it does raise an important issue given that the work upon which it is based explicitly denies that Asp has such selectional properties (Bruening 2014; Embick 2004). There are at least two considerations that can be used as evidence in favor of (38). First, the Spanish AA facts are vastly different from English as can be seen in Section 2 and the simplest way of accounting for them is by claiming that they are adjectival participles that have

\footnotetext{
6 The notation of the selectional property in (38a) is taken from Bruening (2014) and the schematization of what each head does in the structure in (38b) is based on Oltra-Massuet's (2014) analysis of the internal structure of -ble adjectives. I have left out other components of the structure for simplicity. For example, it is possible that an additional 'categorizer' such as $a$ or A is merged above Asp, which converts the structure into an adjective and is the locus for the spell out of agreement morphology.
} 
'external' verbal arguments. Second, not all languages use "past/passive" participial morphology in the exact same way. While detailed studies of English have demonstrated that adjectives formed with "past/passive" participial morphology are for the most part derived from passive and unaccusative verbs, it is by no means the only use of this morphology cross-linguistically. For example, in English, Spanish and other languages, "past/passive” participial morphology appears on nouns as in (39) (Bruening 2014; Nevins and Myler 2014; Varela 2002).

(39) a. bearded, winged, feathered, two-faced, tight-fisted, etc.

b. mal-intencionado, alado, etc.

bad-intentioned, winged

Accounts vary as to whether these should be derived from covert possessive verbs, how they should be linked to canonical adjectival participles and how to account for their varying productivity in different languages (see Bruening 2014 and Myler and Nevins 2014 for different accounts). The point I wish to highlight here is that it is certainly plausible that a language like Spanish might use "past/ passive" morphology to form adjectives in a way that is different from English. While an explanation of why Spanish has Asp with the properties in (38) while English does not (apart from a few examples discussed in Bresnan 1995; Bruening 2014; McIntyre 2013) is beyond the scope of the present paper, one possible avenue to explore for is that a more productive use of (38) in English is blocked because adjectives with same meaning are distributed across other adjectivizing heads such as -ing, -ful, -ate, -ous and $-y$. Summing up, while the proposal in (38) departs from how Asp is used in previous syntactic approaches to adjectival participle formation in English, it is motivated by the data in presented in Section 2 for Spanish and can be understood more broadly as one of many potential ways in which "past/passive" participial morphology is employed to create adjectives cross-linguistically.

Another important question that (38b) raises regards how it can account for why the argument of the adjective is interpreted as the external argument of the verbal source. There is no consensus on how to model it (see McIntyre 2013 for a critical review of both lexicalist and non-lexicalist perspectives). There are at least three possible ways of establishing this connection for a structure like (38b). First, the DP in spec, Voice could move to position outside of Asp where it could then be the argument of an attributive or predicative use of AspP. Second, the spec, Voice could be occupied by PRO and controlled by a DP outside of AspP. Third, the spec, Voice position could be occupied by an operator that moves to spec of AspP and lambda abstracts creating a predicate of individuals. 
I leave a definitive answer to this question to future research, and note that for the purposes of the present argument, the most important point is to establish that the spec, Voice position, rather than an internal argument position, is the one that is connected to an AspP-external position. This is what separates AAs from more canonical types of adjectival participles.

With this basic idea now in place, I will separately go into how (38), coupled with other assumptions in the DM framework that it comes from, provides a better account of the properties outlined in Section 2 than any of the previous proposals for AAs in Spanish or English discussed in Section 3.

\subsection{Types of AAs}

In order to accurately account for these three types of AAs, I propose that Asp in (38) comes in three 'flavors': Asp ${ }_{R}, A \operatorname{Asp}_{\mathrm{H}-\mathrm{P}}$ and $\mathrm{Asp}_{\mathrm{G}}$. Note that this is completely in line with both Bruening (2014) and Embick (2004), which are both crucially based on the idea that Asp/Adj heads have different selectional and semantic properties. What is proposed by Bruening (2014) is particularly relevant for the task at hand. His Adj head binds the event argument of a verb and the external argument variable when it selects Voice $_{\text {tr }}$ but it only binds the event argument when it selects Voice $_{\text {intr }}$ since there is no external argument variable in adjectival participles derived from an unaccusative verb. In both cases, the head Adj creates a resultant state by binding one or more unsaturated variables that are part of the meaning of the verbal base. I claim that the Asp head responsible for creating AAs does the same kind of work. Like Bruening's

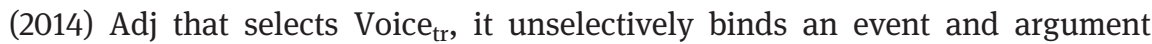
variable. However, unlike Bruening's Adj, Asp does not always create a state or property by existentially binding all of the unsaturated variables in the verbal construction it selects. The labels on the different types of Asp correspond to the operators that bind the unsaturated variables in the verbal structure that Asp selects. These are described in (40).

(40) a. $\operatorname{Asp}_{\mathrm{R}}$ : creates a state by binding the event argument and implicit internal argument variable of a verb with an existential operator

b. Asp $_{\mathrm{H}-\mathrm{P}}$ : creates a property by binding the event argument and implicit internal argument variable of a verb with a habitual operator and then perfectivizing the habitual event

c. Asp $_{\mathrm{G}}$ : creates a property by binding the event argument and implicit internal argument variable of a verb with a generic operator 
Proposing different flavors of operators yields a very simple explanation for why three types of AAs exist and it is in line with many approaches about the semantics of the conversion process from verb to adjective. As mentioned in Section 2, a leading idea in the research on adjectival participles is that the event variable of the verb (and its external argument variable if it is passive) is bound by an existential operator. The idea that this type of variable binding takes place in the creation of adjectives from verbal bases has also been proposed by Oltra-Massuet (2014) for -ble adjectives, which involve existential binding and modalization of the event argument of the verb. Thus, different types of adjectives result from different ways of binding the event variable of the verb in the process of conversion from verb to adjective. In addition, it has been proposed independently that different languages may link operators to different types of morphology (see Lekakou 2005 for an account of modals that is based on different ways in which generic operators are linked, or not, to tense morphology in Greek/French versus Germanic). Therefore, it is not entirely unexpected that a language may have different 'flavors' of an operator whose main function is to unselectively bind variables in the conversion process from adjective to verb and that some variation between languages (like Spanish and English) will be observed in this respect.

Another positive consequence of (40) is that the generalizations outlined in Section 2.2 regarding the types of verbal constructions that provide the "inputs" to the different classes of AAs can also be easily accounted for. The proposal is not that the AAs are actually derived from tensed verbs but rather that the way in which the interpretative component of the grammar (the Encyclopedia in DM) assigns an interpretation to a given root with no object in combination with a type of aspectual/tense operator is the same across different types of constructions (verbs and adjectives in this case). For instance, the interpretation of comer (= eat) in the absence of a theme in past tense is "eat some quantity of food." The same interpretation is assigned to this root when it appears in a resultative $\mathrm{AA}$ as in (41b). What matters here is that both constructions share a VoiceP and the same type of operator that binds the event and internal argument variables introduced below VoiceP.
a. Los invitados comieron
The guests ate
b. Los invitados están bien comidos
The guests are well eaten
'The guests are full'

I argue that this is what enables us to account for the generalization identified in Armstrong (2011) and discussed in Section 2.2: if there is no interpretation that 
can be assigned to missing object in an episodic contexts as a verb then there will also be no interpretation assigned to it as a resultative AA. This is what is shown in (42).

(42) a. *Los agentes vendieron

The agents sold

b. ${ }^{*}$ Los agentes estấn muy vendidos

The agents are very sold

Intended: 'The agents are in a state of having sold a lot (of things)'

To close this section, I propose that a natural way of accounting for copula selection in AAs is by linking copula choice with the type of Asp head. While all canonical adjectival participles are treated as resultatives and combine with ESTAR, the stage-level copula verb form adjectives, this is not the case with AAs. $A_{\mathrm{sp}}$ gives rise to a stage-level adjectives with a resultative interpretation that combines with ESTAR while $\mathrm{Asp}_{\mathrm{H}-\mathrm{P}}$ and $\mathrm{Asp}_{\mathrm{G}}$ both give rise to individual-level properties that combine with SER as shown in (43) (see Camacho 2012 and Fábregas 2012 for recent overviews of the ser/estar distinction and SL/IL distinction in Spanish). As far as I can tell, this has not been addressed with much attention in the literature. The properties of the three aspectual operators proposed here yields a straightforward account of the difference.

(43) a. Esos chicos $\left\{{ }^{*}\right.$ son/están $\}$ fumados (resultative)

Those kids SER.3p/ESTAR.3p smoked

'Those kids are high/stoned'

b. Esos chicos \{son/*están\} muy viajados (habitual perfective)

Those kids SER.3p/ESTAR.3p very traveled

'Those kids are widely-traveled'

c. Esos chicos \{son/*están\} precavidos (tend-to property)

Those kids SER.3p/ESTAR.3p watched out

'Those kids are cautious'

\subsection{Modification}

I will remain agnostic regarding where PP and adverbial modifiers merge with respect to AspP (externally or internally) since these issues are still to be worked out in any theory of adjectival participle formation (see Gehrke and Marco 2014; Meltzer-Asscher 2011 and references therein for many important observations and proposals regarding by-phrases and adverbial modification of adjectival 
passives). The modifiers in bold could be treated as modifiers of the state/ property created by the adjectivizing head in (44) or as adjuncts of a verbal projection below the adjectivizing head.

(44) a. Este cuadro parece pintado por un niño; no sé por qué This picture seems painted by a child; NEG I know why todos creen que es tan bueno all think that is so good

'This picture seems painted by a child; I don't know why everyone thinks it's so good'

b. Las maletas están amarradas al carro con soga

The suitcases are tied to.the car with rope

'The suitcases are tied to the car with rope'

c. El cuarto quedó cuidadosamente limpiado

The room remained carefully cleaned

'The room remained carefully cleaned'

d. un niño * (recién) nacido

a child recently born

'a new-born child'

Since such modifiers are subject to semantic restrictions based on particular roots, the details of which have not be fully worked out, whatever ends up being the best way of accounting for their presence in (44) would also extend naturally to examples like (45).

(45) a. un correspondiente muy viajada en la región

a correspondent very traveled in the region

'a correspondent well-traveled in the region'

b. un abogado *(bien)hablado

a lawyer *(well)spoken

The main point here is not to provide an explicit and detailed theory of how event-sensitive modification of adjectival participles works, but rather to point out that the same kind of modification exists in both canonical adjectival participles and AAs. Thus, regardless of how these questions are worked out in a lexicalist or syntactic theory of adjectival participles, the solution should be equally applicable to AAs. An important question that deserves further attention is why such modification is much more limited in AAs than in canonical adjectival participles (even though it is not fully productive in this latter class either). 
Unlike PP and adverbial modifiers, degree modification is very productive and even obligatory for some speakers with some AAs. The most interesting fact about degree modification as mentioned in Section 2.3 is that that in many AAs, the dimension of the scale that provides the degree argument of the adjective is determined in terms of some aspect of the source verb. As discussed in Kennedy and McNally (2005), this would be quite unexpected if some derivational process has not occurred. The example in (46) (repeated from (30) above) shows that degree terms may target different dimensions associated with verbal source or the derived state/property).
(46)
a. Están bastante bebidos
They are quite drunk
'They are quite drunk' (bastante=amount of alcohol/degree of drunkenness)
b. María es muy viajada
María is very traveled
'María is well-traveled' (well = amount of times/places traveled to)
c. Un comediante bien entretenido
A comedian well entertained
'A really entertaining comedian' (bien = intensity of entertainment)

I will follow Bosque and Masullo (1998) in assuming that degree quantifiers may merge externally to a category they modify but be linked to a meaning component that is part of the derivational history of that category. In the case of (46a), bastante is a degree quantifier the merges in the specifier of Deg, which is part of the functional domain of the derived adjective. The dimension of the scale provided by the adjective could be the amount of alcohol drunk (a component inherited from the source verb) or the state of being drunk.

(47)

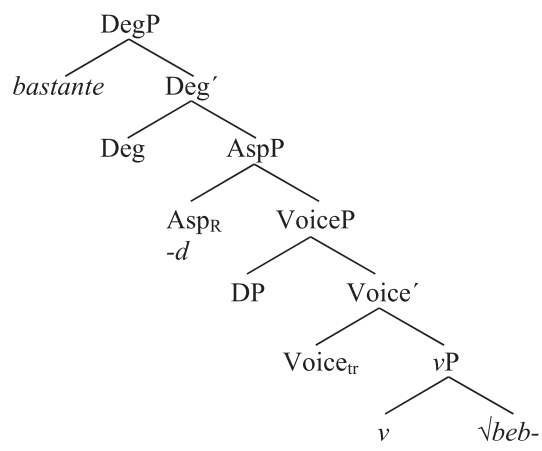


Finally, there are cases such as (46b) in which the absence of a degree term makes the AA somewhat unnatural. I propose that, especially in the case of habitual perfective AAs, the property described by the derived adjective is only felicitous if it holds to a high standard on the scale provided by the AA. So, the adjectives leido ( = read) or viajado (= traveled) are only interpreted as holding to high degrees and thus require a degree modifier muy to be used felicitously.

\subsection{Productivity and semantic drift}

As mentioned in Section 2.4, an important difference between AAs on the one hand and canonical adjectival participles on the other is that the former are not productive outside small groups of verb roots that are related to the same semantic fields (consumption, learning, traveling, object-experiencer verbs, etc). This has been used to relegate them to the status of unstructured, 'lexicalized' adjectives. However, we have seen in the previous sections that such an analysis misses a great number of properties that AAs share with other canonical adjectival participles. The question is how we can reconcile these two apparently contradictory facets of AAs.

While future diachronic and experimental studies are needed to confirm the remarks that follow, I would like to propose as a starting point that AAs are marked with respect to canonical adjectival participles and they most likely originated as special adjectival uses of particular participles that fit into a certain semantic categories in which a resultant state or property could be easily applied to a "doer" rather than an "undergoer" of the verbal source. Consumption verbs provide potentially salient resultant states that hold of the consumer, thus these are apt roots for giving rise to the interpretations that the grammar assigns to resultative AAs. If a special use spreads by analogy to other related verbs and then appears in ones that are not semantically related, as is the case with resultative AAs, we might posit that there is a degree productivity gained by the structure underlying the AA and that speakers do use a similar mechanism in forming and interpreting these adjectival participles as they use with other ones. The same idea could also apply to habitual perfectives and tend-to properties, but in these cases, it is the assignment of some attained state of status (through repetition of some action) that is culturally relevant or the possession of some property (in terms of a type of action that is performed) that is culturally relevant.

While this idea is mere speculation at present, it is worth mentioning that such semantic restrictions appear to be operative in canonical adjectival participles as well. For instance, verbs that do not entail changes of state, do not, at 
least in the absence of a very specific context, give rise to adjectival participles (Bosque 1999; Bresnan 1995; Kratzer 2000; McIntyre 2013; among others)
a. ${ }^{\star}$ La mesa está tocada
The table is touched
b. `Juan está presentado a María
Juan is introduced to María

Taking these observations into consideration, I claim that lack of productivity of AAs is due to a semantic/conceptual restriction on how the output of the syntactic structure that is built on top of the root is interpreted by the Encyclopedia (in DM) and not because the syntactic process that builds AAs in the first place is impossible or non-existent. To conclude this part, the example in (48), which is repeated from (31) above, is unacceptable because there is no concept in the list accessed by the Encyclopedia that can be appropriately linked to the resultative AA that is built on top of the root cant- (sing) that means "a person who has sung a lot."

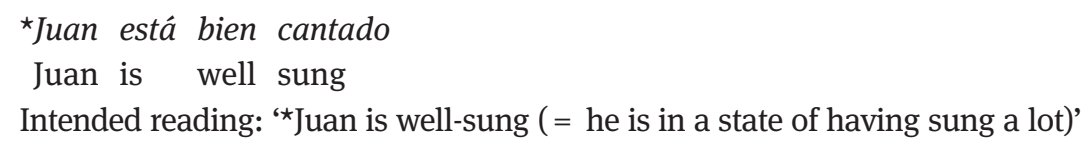

Finally, it was also noted in Section 2.4 that AAs exhibit semantic drift with respect to their source verbs. We saw above that this is by no means a unique characteristic of AAs with respect to other adjectival participles. Since this is so, I will follow Bruening (2014) in treating semantic drift as simply a form of idiomatic interpretation. For Bruening (2014), all adjectival participles, regardless of whether they have special interpretations with respect to verbal sources or are derived from "missing” verbal inputs, are still deverbal adjectives derived from a passive or unaccusative source. Applying this idea to cases such as agarrado (= stingy), negado ( = useless) and others, the conclusion is that these AAs have the same syntactic structure as any other tend-to property AA. The main difference is that the entire structure defined by the AspP constituent has a special interpretation.

\subsection{Summary}

In this section an analysis of AAs has been presented that accounts in a straightforward way for the basic properties presented in Section 2. This marks a major improvement with respect to previous analyses that, for the most part, relegate AAs to a small group of idiosyncratic adjectives with no internal 
structure that are only formally related to other, more productive adjectival participles. The analysis outlined here extends the syntactic approaches of Bruening (2014) and Embick (2004) to languages in which "past/passive" morphology can actually be used to derive an adjective from an active transitive or unergative verbal source. Motivation for this move has been presented throughout this paper and it was shown here that all of the properties of AAs follow from this and other general principles that are used in DM to explain the properties of canonical adjectival participles.

\section{Conclusion}

The main contribution of this paper has been to bring a class of adjectival participles in Spanish called participios activos into the theoretical spotlight. It was argued that the descriptive properties of these adjectives motivate treating them as adjectival antipassives (AAs) and that a straightforward way of accounting for their properties involves increasing the number of functions of "past/ passive" participial morphology to include that of forming adjectival participles from active/unergative verbal bases. This observation is something that both lexicalist and non-lexicalist approaches to adjectival participles have had difficulty accounting for and a new proposal was implemented using the syntactic framework outlined in Bruening (2014) and Embick (2004). With this basic idea in place, I hope that AAs may be investigated in more detail in the future in order to answer many of the questions that have been raised here but, for reasons of space, have not be given a detailed answer.

Acknowledgment: I would like to thank the audience at the Workshop on Aspect and Argument Structure of Adjectives and Participles 1 (WAASAP 1) at the University of Greenwich in June 2012 as well as the anonymous reviewers of The Linguistic Review for helpful comments on the present work. All errors and omissions are my responsibility.

\section{References}

Alexiadou, Artemis \& Elena Anagnostopoulou. 2008. Structuring participles. In C. Chang \& H. Haynie (eds.), Proceedings of the $26^{\text {th }}$ west coast conference on formal linguistics, 33-41. Somverville, MA: Cascadilla Press.

Arad, Maya. 2002. Universal features and language-particular morphemes. In A. Alexiadou (ed.), Theoretical approaches to universals, 15-39. Amsterdam: Benjamins. 
Armstrong, Grant. 2011. Two classes of transitive verbs: evidence from Spanish. Georgetown University, unpublished PhD Dissertation.

Belletti, Adriana \& Luigi Rizzi. 1988. Psych verbs and $\theta$-theory. Natural Language and Linguistic Theory 6. 291-352.

Borer, Hagit. 1984. The projection principle and rules of morphology. In C. Jones \& P. Sells (eds.), Proceedings of the $14^{\text {th }}$ annual meeting of NELS, 16-33. Amherst, MA: GLSA.

Borgonovo, Claudia. 1999. Participios activos. Nueva Revista de Filología Hispánica XLVII. 281-303.

Bosque, Ignacio. 1999. El sintagma adjectival. Modificadores y complementos del adjetivo. Adjetivo y participio. In I. Bosque \& V. Demonte (eds.), Gramática descriptiva de la lengua española, Volumen 1, 217-310. Madrid: Espasa-Calpe.

Bosque, Ignacio \& Pacual José Masullo. 1998. On verbal quantification in Spanish. In O. Fullana \& F. Roca (eds.), Studies on the syntax of central romance languages, 9-63. Girona: Universitat de Girona.

Bowers, John. 2010. Arguments as relations. Cambridge, MA: MIT Press.

Bresnan, Joan. 1995. Lexicality and argument structure. Paper given at the Paris Syntax and Semantics Conference, 1995.

Bruening, Benjamin. 2014. Word formation is syntactic: Adjectival passives in English. Natural Language and Linguistic Theory 32. 363-422.

Camacho, José. 2012. Ser and Estar: The Individual/Stage-level Distinction and Aspectual Predication. In J.I. Hualde et al. (eds.), The Handbook of Hispanic Linguistics, 453-475. Malden, MA: Wiley-Blackwell.

Di Tullio, Ángela. 2008. Participios y adjetivos. Verba 61. 99-125.

Dubinsky, Stanley \& Silvester Ron Simango. 1996. Passive and stative in Chichewa: Evidence for modular distinctions in grammar. Language 72. 749-781

Embick, David. 2004. On the structure of resultative participles in English. Linguistic Inquiry 35. 355-392.

Embick, David \& Rolf Noyer. 2007. Distributed morphology and the syntax/morphology interface. In G. Ramchand \& C. Reiss (eds.), The Oxford handbook of linguistic interfaces, 289325. Oxford: Oxford University Press.

Fábregas, Antonio. 2012. A guide to IL and SL in Spanish: Properties, problems and proposals. Borealis: An International Journal of Hispanic Linguistics 1(2). 1-71.

Felíu Arquiola, Elena. 2008. La codificación de los participios activos. Verba 61. 165-180.

Gehrke, Berit \& Cristina Marco. 2014. Different by-phrases with adjectival and verbal passives: Evidence from Spanish corpus data. Lingua 149. 188-214.

Hale, Ken. \& Samuel J. Keyser. 2002. Prolegomenon to a Theory of Argument Structure. Cambridge, MA: MIT Press.

Horvath, Julia \& Tal Siloni. 2008. Active lexicon: Adjectival and verbal passives. In S. ArmonLotem, G.Danon \& S. Rothstein (eds.), Current issues in generative Hebrew linguistics, 105-134. Amsterdam: John Benjamins.

Kennedy, Christopher \& Louise McNally. 2005. Scale structure, degree modification, and the semantics of gradable predicates. Language 81. 345-381.

Koontz-Garboden, Andrew. 2010. The lexical semantics of derived statives. Linguistics and Philosophy 33. 285-324.

Kratzer, Angelika. 2000. Building statives. In L.J. Conathan et al. (eds.), Proceedings of the $26^{\text {th }}$ annual meeting of the Berkeley Linguistics Society, 385-399. Berkeley, CA: UC Berkeley Linguistics Society. 
Krifka, Manfred, Francis Jeffry Pelletier, Gregory N. Carlson, Alice ter Meulen, Gennaro Chierchia, and Godehard Link. 1995. Genericity: An introduction. In G. Carlson \& F. Pelletier (eds.), The generic book, 1-124. Chicago: University of Chicago Press.

Lekakou, Maria. 2005. In the middle, somewhat elevated. The semantics of middles and its crosslinguistic realization. University College London, unpublished PhD Dissertation.

Levin, Beth. \& Malka Rappaport. 1986. The formation of adjectival passives. Linguistic Inquiry 17. 623-661.

Levin, Beth \& Malka Rappaport Hovav. 1995. Unaccusativity at the syntax - lexical semantics interface. Cambridge, MA: MIT Press.

Marantz, Alec. 2013. Locality domains for contextual allomorphy across the interfaces. In A. Marantz \& O. Matushansky (eds.), Distributed morphology today: Essays in honor of Morris Halle, 95-115. Cambridge, MA: MIT Press.

McIntyre, Andrew. 2013. Adjectival passives and adjectival participles in English.

In A. Alexiadou \& F. Schäfer (eds.), Non-canonical passives, 21-41. Amsterdam: John Benjamins.

Meltzer-Asscher, Aya. 2011. Adjectival passives in Hebrew: evidence for parallelism between the adjectival and verbal systems. Natural Language and Linguistic Theory 29. 815-855.

Mittwoch, Anita. 2005. Unspecified arguments in episodic and habitual sentences. In N. Erteschik-Shir \& T. Rapaport (eds.), The syntax of aspect, 237-254. Oxford: Oxford University Press.

Nevins, Andrew \& Neil Myler. 2014. A brown-eyed girl. UCLA working papers in linguistics, Papers in honor Sarah Van Wagenen. Available at lingbuzz/002021.

Oltra-Massuet, Isabel. 1999. On the notion of theme vowel: A new approach to Catalan verbal morphology. MIT, unpublished MA Thesis.

Oltra-Massuet, Isabel. 2014. Deverbal adjectives at the interface. A crosslinguistic investigation into the morphology, syntax and semantics of -ble. Berlin: Mouton De Gruyter

Piera, Carlos \& Soledad Varela. 1999. Relaciones entre morfología y sintaxis. In I. Bosque \& V. Demonte (eds.), Gramática descriptiva de la lengua española, Volumen 3, 4367-4422. Madrid: Espasa-Calpe.

Rainer, Franz. 1999. La derivación adjetival. In I. Bosque \& V. Demonte (eds.), Gramática descriptiva de la lengua española, Volumen 3, 4595-4643. Madrid: Espasa-Calpe.

Real Academia Española. 2009. Nueva gramática de la lengua española. Madrid: Espasa-Calpe. Rizzi, Luigi. 1986. Null objects in Italian and the theory of pro. Linguistic Inquiry 17. 501-557.

Sleeman, Petra. 2011. Verbal and adjectival participles: Position and internal structure. Lingua 121. 1569-1587.

Varela, Soledad. 2002. Active or subjective adjectival-participles in Spanish. In J.K. Lee, K.L. Geeslin \& J.C. Clements (eds.), Structure, meaning and acquisition in Spanish: Papers from the $4^{\text {th }}$ Hispanic linguistics symposium, 304-316. Somerville, MA: Cascadilla Press.

Varela, Soledad. 2003. Lexical morphology revisited: Form/meaning correspondences in adjectival psych participles. In G. Booij et al. (eds.), Topics in morphology: Selected papers from the Third Mediterranean morphology meeting, 51-74. Barcelona: Universitat Pompeu Fabra.

Varela, Soledad. 2008. Las categorías híbridas: comparación entre dos tipos de análisis. Verba 61. 89-98.

Wasow, Thomas. 1977. Transformations and the lexicon. In P. Culicover, T. Wasow \& A. Akmajian (eds.), Formal syntax, 327-360. New York: Academic Press. 